
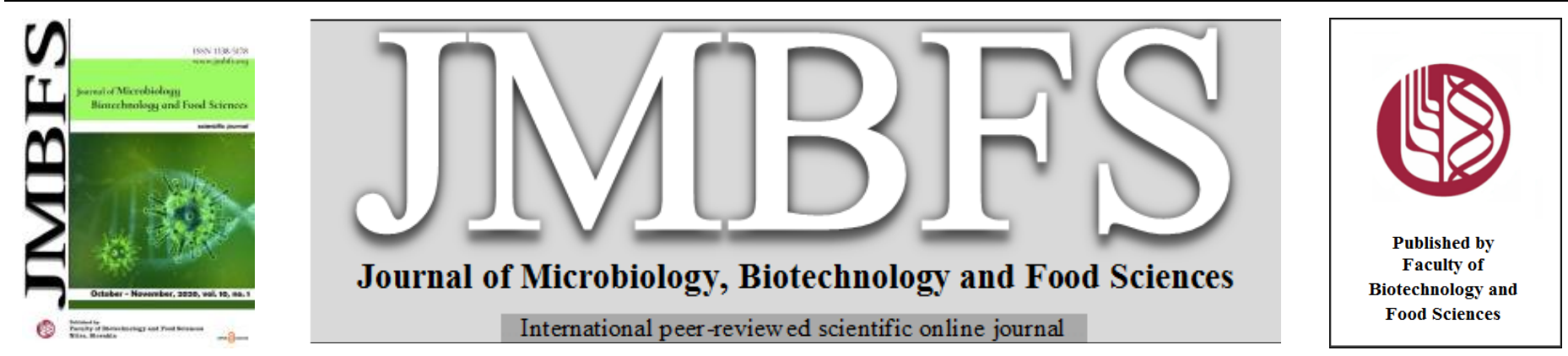

\title{
PRODUCTION AND OPTIMIZATION OF CYCLODEXTRIN GLUCANOTRANFERASE FROM BACILLUS SP. SS2
}

\author{
Dhwani Upadhyay ${ }^{1}$, Divya Shrivastava ${ }^{1}$ Anita Chauhan ${ }^{2}$, Niraj Kumar Singh ${ }^{2}$ and Niha Mohan Kulshreshtha ${ }^{1,3^{*}}$
}

Address(es): Dr. Niha Mohan Kulshreshtha,

${ }^{1}$ School of Life Sciences, Jaipur National University, Jaipur, Rajasthan, India-302025.

${ }^{2}$ Shri A.N. Patel P.G. Institute, Anand, Gujarat, India-388001.

${ }^{3}$ Department of Civil Engineering, Malaviya National Institute of Technology, Jaipur, Rajasthan, India-302017.

*Corresponding author: nihamk24@gmail.com

doi: 10.15414/jmbfs.2020.10.2.159-165

\section{ARTICLE INFO}

Received 11. 4. 2019

Revised 2. 6. 2020

Accepted 2. 6. 2020

Published 1. 10. 2020

Regular article

OPEN 2 ACCESS

\begin{abstract}
An extracellular cyclodextrin glucanotranferase enzyme producing bacterium was isolated from the soil sample collected from Dumas Beach, Surat, India. The isolate was biochemically, physiologically, and phylogenetically characterized and was identified as a strain of Bacillus cereus group. The production of CGTase enzyme was optimized using various starch sources as substrates such as soluble starch, corn starch, potato starch, and rice starch. The enzyme production was found to be maximum when potato starch was added in the medium as substrate. The enzyme activity was measured as $5.132 \pm 0.25 \mathrm{U} / \mathrm{mL}$ in soluble starch, $8.423 \pm 0.33 \mathrm{U} / \mathrm{mL}$ in corn starch, $14.329 \pm 0.14$ $\mathrm{U} / \mathrm{mL}$ in potato starch, and $12.762 \pm 0.09 \mathrm{U} / \mathrm{mL}$ in rice starch. The optimization of operating parameters such as $\mathrm{pH}$, incubation temperature, potato starch concentration, incubation time, and agitation speed affecting enzyme production was further carried out using Response Surface Methodology, a combined method of statistical and mathematical approach. Central Composite Design was selected for optimization and the optimum levels of these parameters were identified as $8.8,38^{\circ} \mathrm{C}, 2.2 \%, 50 \mathrm{~h}$, and $200 \mathrm{rpm}$ for $\mathrm{pH}$, incubation temperature, potato starch concentration, incubation time, and agitation speed respectively. The final CGTase enzyme activity at the optimum levels of all the factors was measured to be as $38.313 \mathrm{U} / \mathrm{mL}$ which was in agreement with the software predicted enzyme activity of $39.901 \mathrm{U} / \mathrm{mL}$ and was more than twice the original activity. This study demonstrates the utility of strain SS2 for CGTase production which can be used as an alternative for commercial cyclodextrin production.
\end{abstract}

Keywords: cyclodextrin glucanotranferase, Optimization, Central Composite Design, Cyclodextrins

\section{INTRODUCTION}

Cyclodextrin glucanotransferase is a versatile enzyme produced by some microorganisms that are capable of acting on starch and related carbohydrates. The enzyme catalyzes reactions such as cyclization, hydrolysis, coupling, and disproportionation. The cyclization reaction is the most beneficial among all the reactions as it produces a non-reducing cyclic molecule known as cyclodextrin (CD). Cyclodextrin is an oligosaccharide having glucopyranose units bonded with $\alpha(1,4)$ linkage. It possess an external hydrophilic and internal hydrophobic surface conferring it with an ability to encapsulate various guest molecules in its cyclic cavity (Di Cagno, 2017). Due to its inclusion complex forming capability, cyclodextrin is used in multiple industries such as pharmaceutical, cosmetic, agriculture, environmental, plastic, chemical, textile, food, medical for diverse purposes (Sharma and Baldi, 2016). There are three types of cyclodextrins based on the number of glucopyranose units. The cyclodextrins which contain 6 glucopyranose units are known as $\alpha$ cyclodextrins whereas, 7 and 8 glucopyranose comprising cyclodextrins are called as $\beta$ and $\gamma$ cyclodextrins respectively (Jansook et al., 2018). The superior intriguing qualities of cyclodextrins are to shelter the guest molecules from biotic and abiotic origins such as heat, light, and microbial degradation, and the capability to transform their properties such as solubility, stability, chemical reactivity, color and odour (Kfoury et al., 2018). Among the three types of cyclodextrins, $\beta$-cyclodextrins are routinely utilized for complexing a variety of guest molecules owing to their high stability and low solubility and thus have high commercial value (Upadhyay et al., 2018). The CGTase enzyme is known to be produced mostly by bacterial strains such as Bacillus circulans (Costa et al., 2015), Microbacterium terrae (Rajput et al., 2016), Bacillus flexus (Reddy et al., 2017), Bacillus clarkii (Wu et al., 2012) and Amphibacillus sp. (Ibrahim et al., 2012). However, some hyperthermophilic archaea, for instance, Haloferax mediterranei (Bautista et al., 2012), Thermococcus kodakaraensis (Rashid et al., 2002), and Pyrococcus furiosus (Lee et al., 2007) are also proficient in secreting the enzyme.
The production of cyclodextrins using CGTase enzyme results in a mixture of all the three types of cyclodextrins $(\alpha, \beta$ and $\gamma)$. The inability of wild type microorganisms to produce adequate amount of single type of cyclodextrin leads to increased production cost as a result of requirement of additional purification step for extraction of the desired type of cyclodextrin from the mixture of all the cyclodextrins. The problem can be partly overcome by use of strains that produce cyclodextrins in adequate amount so that the production cycle becomes economically feasible. A large number of genetically engineered CGTase overexpressing strains have been developed (Leemhuis et al., 2010) but they suffer from an inherent stability issue for long term application (Qi and Zimmermann, 2005). Looking for novel, high CGTase producing strains from unique environmental niches and optimization of the production medium that may further increase the efficiency of these strains is a more straightforward and simple approach. Moreover, the wild type isolates are expected to retain their characteristics for many generations.

In the present study, we have reported the isolation and characterization of a CGTase producing strain Bacillus sp. SS2. Both conventional and statistical methods were used to optimize the production medium. The enzyme activity was estimated using various starches such as soluble starch, corn starch, potato starch, and rice starch using the conventional method. Further, various operating parameters such as $\mathrm{pH}$, incubation temperature, potato starch concentration, incubation time, and agitation speed were optimized using a combined statistical and mathematical tool known as response surface methodology. This methodology bypasses the conventional single factor optimization and allows study of more than one factor simultaneously. It also generates contour plots showing interaction between the factors and fits the experimental data by least squares technique to calculate the optimal response of the system (Montgomery et al., 2009; Vining and Kowalski 2010). CCD has been used by many researchers to identify optimal reaction conditions (de Oliveira et al., 2019; Sreedharan et al., 2019). The current study was aimed to optimize the CGTase production from a wild type bacterial 
strain using CCD which may reduce the production cost of cyclodextrins and may prove as a viable alternative for commercial CGTase production.

\section{MATERIALS AND METHODS}

\section{Sample collection and screening of CGTase producing microorganisms}

Soil sample was collected from Dumas beach, Surat, Gujarat, India $\left(21^{\circ} 4^{\prime} 45^{\prime \prime}\right.$ $\mathrm{N}, 72^{\circ} 42^{\prime} 55^{\prime \prime} \mathrm{E}$ ) in autoclaved glass jar using sterilized gloves and spatula. $0.1 \mathrm{~g}$ of soil sample was added to $500 \mathrm{~mL}$ of autoclaved Horikoshi-II medium (Horikoshi, 2003) which was supplemented with $10 \mathrm{~g}$ soluble starch, $5 \mathrm{~g}$ peptone, 5 g yeast extract, $1 \mathrm{~g} \mathrm{~K}_{2} \mathrm{HPO}_{4}$, and $0.2 \mathrm{~g} \mathrm{MgSO}_{4} .7 \mathrm{H}_{2} \mathrm{O} .10 \% \mathrm{Na}_{2} \mathrm{CO}_{3}$ was separately added to the medium after autoclaving to adjust the $\mathrm{pH}$ at 9 . The soil containing medium was incubated at $37^{\circ} \mathrm{C}$ for $24 \mathrm{~h}, 120 \mathrm{rpm}$. Following incubation, the sample was diluted appropriately in normal saline and spread onto the Horikoshi-II agar plates prepared by adding $2 \%$ agar to the liquid Horikoshi-II medium. All the bacterial colonies were separated and screened for CGTase production according to the method described by Park et al. (1989). The screening medium was prepared by adding $0.035 \mathrm{mM}$ phenolphthalein dye, $0.030 \mathrm{mM}$ methyl orange dye (filter sterilized with 0.2 micron filter), and $2 \%$ agar to the sterilized liquid Horikoshi-II medium just before pouring of plates. The plates were punched using cork-borer at the centre to form a well in which $100 \mu \mathrm{L}$ of cell-free supernatants of isolates grown in liquid Horikoshi II medium were added. The plates were incubated at for 24 to $48 \mathrm{~h}$ at $37^{\circ} \mathrm{C}$ and regularly inspected for the development of halo zones. The bacterial isolates producing yellowish halo zone around the wells were considered as CGTase positive, and its culture supernatant served as crude CGTase enzyme.

\section{CGTase enzyme activity assay}

CGTase activity was measured by PHP method described by Goel and Nene (1995). Briefly, $1 \mathrm{~mL}$ cell-free supernatant of $24 \mathrm{~h}$ old bacterial culture grown in Horikoshi -II medium was added to $1 \mathrm{~mL} 1 \%$ starch solution prepared in $50 \mathrm{mM}$ Tris- $\mathrm{HCl}$ buffer solution ( $\mathrm{pH}-7)$. The tubes containing the enzyme substrate mixture were incubated at $60^{\circ} \mathrm{C}$ in a water bath for 20 minutes. Later, the enzymatic reaction was prohibited by quick cooling of tubes on ice for 10 minutes The assay reagent of PHP method, i.e. $4 \mathrm{~mL}$ of working phenolphthalein was added to the tubes. The working phenolphthalein was prepared by adding $4 \mathrm{~mL}$ of ethanol and $1 \mathrm{~mL}$ of $4 \mathrm{mM}$ phenolphthalein to $100 \mathrm{~mL} 125 \mathrm{mM} \mathrm{Na}_{2} \mathrm{CO}_{3}$ solution. After the quick mixing of components, the solution was subjected to optical density measurement at $550 \mathrm{~nm}$. A control reaction was prepared by replacing enzyme with Tris- $\mathrm{HCl}$ buffer (pH-7) 1 Unit of the enzyme is defined as the microgram of product formed in 1 minute from per $\mathrm{ml}$ of culture under controlled conditions. In case of the pure enzyme, appropriate dilution was made and the total protein concentration was determined by Bradford'd protein estimation method. The experiments were set up in triplicates.

\section{Identification and characterization of CGTase producing isolate}

To identify the CGTase producing isolate at primary level, Gram's staining and biochemical assays were performed as described in Bergy's Manual of Determinative Biology. Confirmatory identification was carried out by the molecular method of 16S rRNA gene sequencing. The 16S rRNA sequencing was performed at Yaazh Xenomics, Coimbatore, Tamilnadu, India. Strain SS2 was identified as Bacillus sp. using the Identify tool of EzBioCloud server (Chun $\boldsymbol{e}$ al., 2007). The $16 \mathrm{~S}$ rRNA gene sequences of most closely related, valid strains of Bacillus sp. were downloaded from EzBio cloud server and the phylogenetic position of SS2 was identified using these sequences in MEGA X software (Tamura et al., 2007). Briefly, the FASTA sequences of the closely related Bacillus strains along with one outgroup sp. (Geobacillus stearothermophilus, Accession number- NR 040794.1) were used to create multiple sequence alignment using CLUSTALW program within the MEGA software package. The short sequences were manually removed, and alignment was used for phylogenetic tree construction using the neighbor-joining method in the software (Saitou and Nei, 1987). For computation of evolutionary distances, Kimura two parameter method was used (Kimura, 1980). The reliability of the tree was inferred by performing the bootstrap test with 1000 replicates (Felsenstein, 1985).

\section{Optimization of CGTase production medium for isolate SS2}

\section{CGTase production using various starches}

Enzyme production was optimized by measuring the enzyme activity using different types of starches - soluble starch, corn starch, potato starch, and rice starch. $1 \%$ of each substrate was added to separate flasks containing $100 \mathrm{~mL}$ of Horikoshi-II broth (without dyes) and $\mathrm{pH}$ was set to 9 followed by medium sterilization in autoclave at 15 psi for 20 minutes. $1 \mathrm{~mL}$ of 24 h old SS2 bacterial culture was inoculated in all the flasks which were further incubated at $37^{\circ} \mathrm{C}$ for $24 \mathrm{~h}$ at $120 \mathrm{rpm}$. The enzyme activity assay was performed with the cell-free supernatants collected after centrifugation of all the cultures having various starches. The substrate supplemented medium which produced the highest enzyme activity was considered as the best suitable substrate for CGTase production by SS2. The production medium was further optimized using statistical tools taking various operating parameters.

\section{Optimization of CGTase production using Response Surface Methodology}

Response surface methodology was used to optimize various factors that are known to affect enzyme production. The optimization of variable factors such as $\mathrm{pH}$, incubation temperature, incubation time, potato starch concentration, and agitation speed was carried out using Central Composite Design of Design-Expert 11.0 software (Trial Version- State Ease, Inc., MN, USA). All the factors were taken as independent variables to study the variations in response (CGTase enzyme activity) which may occur due to the interaction effect of operating parameters The minimum and maximum values of independent parameters were fixed and entered in the CCD tool which generated a total of 50 runs to analyze the response. According to the design, 50 experiments of different combinations were performed with Horikoshi-II broth. In Horikoshi-II medium, different concentrations of potato starch was added, and the $\mathrm{pH}$ of the medium was adjusted according to the described level. The medium was inoculated with $1 \%$ of $24 \mathrm{~h}$ old bacterial culture followed by incubation at respective temperatures for a specific time interval at provided agitation speeds. The experiments were conducted in duplicates, and their respective inputs were incorporated in the design for statistical analysis. Further, to develop the mathematical model and to estimate the response of independent variables, following second-order polynomial equation was calculated using an automated statistical tool of software.

$\mathrm{Y}=\beta_{0}+\beta_{1} \mathrm{~A}+\beta_{2} \mathrm{~B}+\beta_{3} \mathrm{C}+\beta_{4} \mathrm{D}+\beta_{5} \mathrm{E}+\beta_{12} \mathrm{AB}+\beta_{13} \mathrm{AC}+\beta_{14} \mathrm{AD}+\beta_{15} \mathrm{AE}+\beta_{23} \mathrm{BC}$ $+\beta_{24} \mathrm{BD}+\beta_{25} \mathrm{BE}+\beta_{34} \mathrm{CD}+\beta_{35} \mathrm{CE}+\beta_{45} \mathrm{DE}+\beta_{11} \mathrm{~A}^{2}+\beta_{22} \mathrm{~B}^{2}+\beta_{33} \mathrm{C}^{2}+\beta_{44} \mathrm{D}^{2}+\beta_{55} \mathrm{E}^{2}$ Where, $Y=$ Response (Predicted), $\beta_{0}=$ Interception Coefficient, $\beta_{1}, \beta_{2}, \beta_{3}, \beta_{4}, \beta_{5}=$ Linear Coefficients, $\beta_{12}, \beta_{13}, \beta_{14}, \beta_{15}, \beta_{23}, \beta_{24}, \beta_{25}, \beta_{34}, \beta_{35}, \beta_{45}=$ Interaction Coefficient, $\beta_{11}, \beta_{22}, \beta_{33}, \beta_{44}, \beta_{55}=$ Quadratic Coefficient.

The data were further analyzed by ANOVA, and the significant $\mathrm{p}$-values $(<0.05)$ were used for surface response analysis. The optimal values of operating parameters and their interactions were estimated by three-dimensional response surface graphs and 2-dimensional contour graphs. The predicted results generated after the design were verified by conducting experiments under optimal conditions.

\section{RESULTS AND DISCUSSION}

\section{Screening of CGTase producing microorganisms}

The CGTase producing microorganisms was isolated on Horikoshi-II agar plate supplemented with phenolphthalein and methyl orange dyes. Out of a total of 20 bacterial colonies isolated on the plates, only 1 bacterium (named as SS2) was found to be producing CGTase enzyme. As shown in Figure $1 \mathrm{~A}$, the cell-free supernatant of isolate SS2 produced a yellowish halo ring around the well suggesting the probable presence of $\beta$-CGTase (Vinod and More, 2016). The reduction of the red color of phenolphthalein may have occurred due to the formation of cyclodextrin and phenolphthalein complex, resulting in an intensified shade of methyl orange. The distilled water was used as negative control for this experiment. The presence of CGTase enzyme was confirmed by spectrophotometric CGTase activity assay (PHP assay) which is predominantly sensitive for $\beta$-cyclodextrin (Goel and Nene, 1995). The CGTase activity of the crude enzyme (cell-free supernatant) was found to be $3.57 \mathrm{U} / \mathrm{mL}$, similar to the strain Microbacterium terrae KNR 9, having crude CGTase activity of $4.71 \mathrm{U}$ (Rajput et al., 2016).

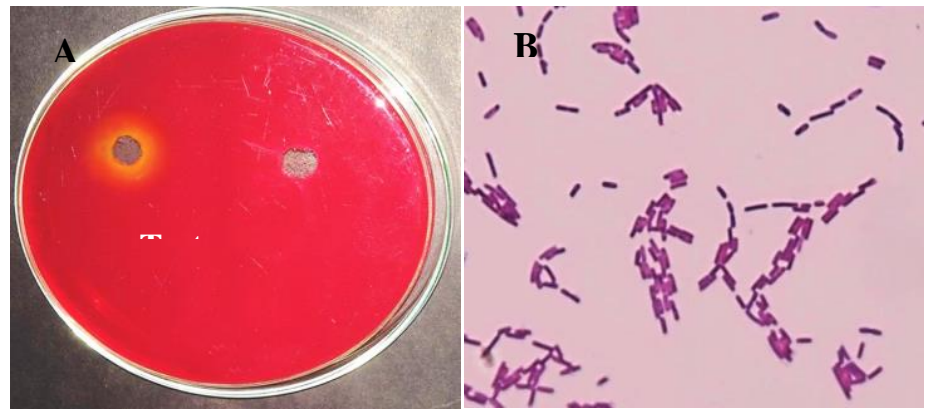

Figure 1 A. CGTase activity plate showing yellow halo zone around the well loaded with crude enzyme, B. Microscopic image of Gram stained SS2 cells 
Identification and characterization of CGTase producing isolate SS2

The bacterial isolate SS2 formed white colored opaque colonies with irregular shape and rough surface on nutrient agar medium after incubation for $20 \pm 2 \mathrm{~h}$ at $30^{\circ}$ C. The colony diameter was observed to be $4-6 \mathrm{~mm}$. The bacterium was found to be Gram positive, forming dense rods (Figure $1 \mathrm{~B}$ ). The biochemical characterization was conducted to decipher the metabolic abilities of the bacterium that may confer a selective advantage to the bacterial isolate, apart from CGTase production. This also provided clues for identification of the isolated strain. As mentioned in Table 1, indole and MR tests produced negative results for SS2 while VP, citrate, urease, catalase, and gelatinase tests were found to be positive. The bacterium can ferment simple sugars such as maltose, fructose, sucrose, dextrose, and lactose but is inefficient for xylose and sorbitol fermentation. The results of biochemical tests along with colony characteristics and Gram's staining were compared with the related species reported in Bergy's Manual of Systematic Bacteriology Volume 1 and Volume 3 (Krieg and Holt, 1984; Staley et al., 1989) and it was confirmed that the isolate SS2 belonged to the family Bacillaceae and genus Bacillus. It was presumed from the biochemical tests that the strain might belong to one of the following species - Bacillus thuringiensis, Bacillus mycoides, Bacillus cereus, Bacillus anthracis, Bacillus subtilis, or Bacillus licheniformis. The genetic identification of bacterium was validated by the molecular procedure of $16 \mathrm{~S}$ rRNA gene sequencing followed by BLAST analysis of the consensus sequence. A BLAST analysis of the consensus sequence revealed that isolate SS2 belongs to the Bacillus cereus group and showed the highest similarity with Bacillus cereus strain D18-4 (Accession number MK300054.1). The 16S rRNA gene sequence of isolate SS2 (1225 bp) has been deposited to NCBI-Genbank (Accession number - MK389411). The phylogenetic analysis of isolate SS2 carried out using MEGA $X$ software shows that the strain clustered with the different species of Bacillus genus such as Bacillus cereus, Bacillus luti, Bacillus albus, Bacillus mycoides, and Bacillus tropicus (Figure 2). Genus Bacillus is known for its biotechnological applications such as hydrolytic enzymes as well as value added products (Kumar et al., 2013; Patel et al., 2019; Porwal et al., 2008) CGTase production from Bacillus genus has been reported previously from the species such as Bacillus clausii (Alves-Prado et al., 2008), Bacillus pseudalcaliphilus (Atanasova et al., 2011), Bacillus clarkii (Wu et al., 2012), Bacillus circulans (Costa et al., 2015) etc.

Table 1 Biochemical Tests for CGTase producing isolate SS2

\begin{tabular}{cc}
\hline Biochemical Test & Experimental Results \\
\hline Indole test & Negative \\
Methyl red test & Negative \\
VP test & Positive \\
Citrate utilization test & Positive \\
Urease test & Positive \\
Gelatinase & Positive \\
Catalase & Positive \\
Starch hydrolysis & Positive \\
Maltose fermentation & Positive \\
Fructose fermentation & Positive \\
Sucrose fermentation & Positive \\
Dextrose fermentation & Positive \\
Lactose fermentation & Positive \\
Xylose fermentation & Negative \\
Sorbitol fermentation & Negative \\
\hline
\end{tabular}

\section{Optimization of CGTase production from SS2}

\section{Optimization of CGTase using various starches}

The CGTase production was estimated after supplementing the production medium with various starches such as soluble starch, corn starch, potato starch, and rice starch. The maximum CGTase activity was observed in the medium supplemented with the potato starch $(14.329 \pm 0.14 \mathrm{U})$. However, rice starch showed the second highest CGTase activity of $12.762 \pm 0.09 \mathrm{U}$. The medium containing corn starch, and soluble starch showed CGTase activities of $8.423 \pm 0.33 \mathrm{U}$ and $5.132 \pm 0.25 \mathrm{U}$ respectively (Table 2 ). CGTase enzyme production is induced by the starch and amylopectin is highly preferred by the enzyme for cyclodextrin formation (Biwer et al., 2002). Potato starch has clusters of amylopectin which comprises 5-10 amylopectin chains per cluster (BeMiller and Whistler, 2009). Therefore, it seems that potato starch plays a vital role in CGTase production from strain SS2. In a previous literature of Microbacterium terrae, potato starch has been identified as a potent substrate for CGTase production among corn, sago, and soluble starches (Rajput et al., 2016). However, in another study carried out by Elbaz et al. (2015) it was observed that Bacillus lehensis produces maximum CGTase enzyme when cultured in medium supplemented with rice starch. CGTase production was further optimized using other operating parameters along with the potato starch as the main substrate.
Table 2 CGTase activity (U) with various starches

\begin{tabular}{cc} 
Starch Type & CGTase Activity (U) \\
\hline Soluble Starch & $5.132 \pm 0.25$ \\
Corn Starch & $8.423 \pm 0.33$ \\
Potato Starch & $14.329 \pm 0.14$ \\
Rice Starch & $12.762 \pm 0.09$ \\
\hline
\end{tabular}

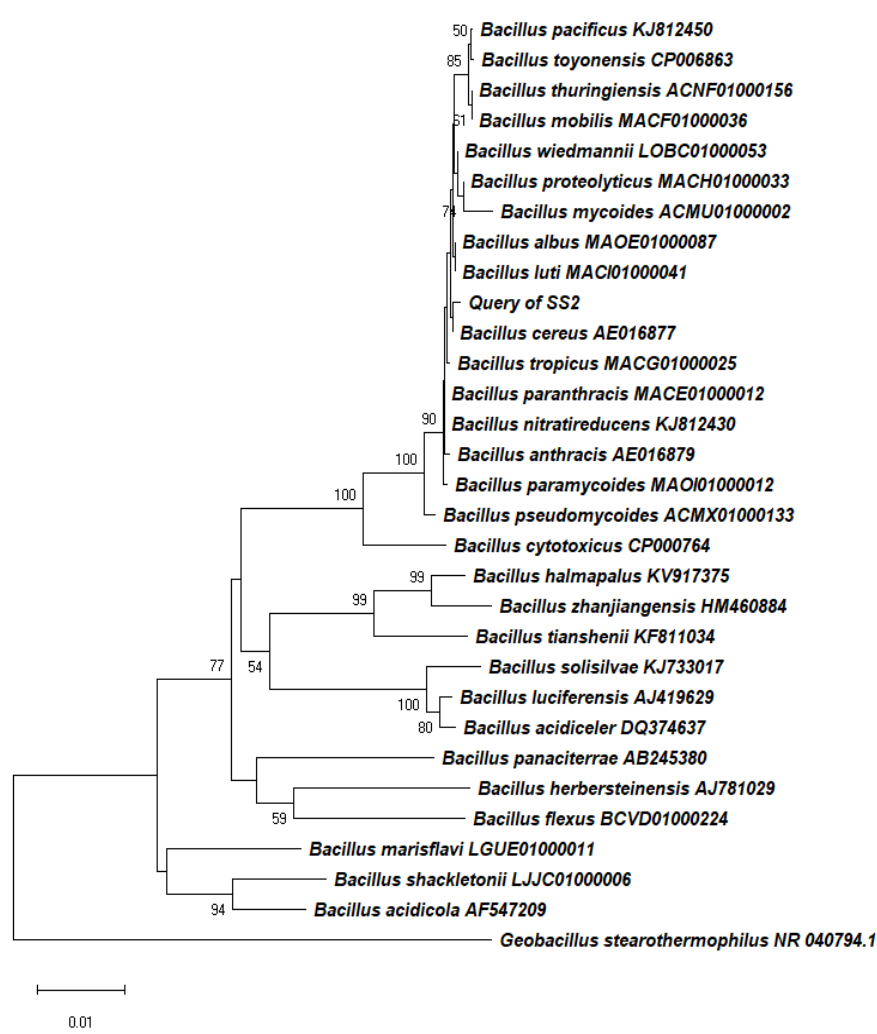

Figure 2 Phylogenetic tree of isolate SS2 presenting evolutionary association between isolate SS2 and 30 taxa of Bacillus genus. The bootstrap values are displayed next to the branch points. The space bar shows the 0.01 substitution per site. Geobacillus stearothermophilus NR_040794.1 was used as outgroup.

\section{Optimization of CGTase production using statistical method (RSM)}

Central composite design of RSM was utilized to optimize the CGTase production at various operating parameters. Factors such as $\mathrm{pH}$, incubation temperature $\left({ }^{\circ} \mathrm{C}\right)$, incubation time $(\mathrm{h})$, potato starch concentration $(\%)$, and agitation speed $(\mathrm{rpm})$ were determined as independent operating parameters for this study, and CGTase activity was considered as the response. The different levels of these parameters used for optimization are mentioned in Table 3 and the responses (CGTase activity) produced after experimenting the combinations of variables, are described in Table 4.

Table 3 Levels of Independent variables for Central Composite Design

\begin{tabular}{lccc}
\hline Independent Variables & -1 Level & 0 Level & +1 Level \\
\hline $\mathbf{p H}$ & 6 & 8 & 10 \\
$\begin{array}{l}\text { Incubation temperature } \\
\left({ }^{\circ} \mathrm{C}\right)\end{array}$ & 25 & 35 & 45 \\
Incubation time (h) & 24 & 48 & 72 \\
$\begin{array}{l}\text { Potato starch concentration } \\
(\%)\end{array}$ & 0.50 & 1.75 & 3.0 \\
Agitation speed (RPM) & 100 & 200 & 300 \\
\hline
\end{tabular}


Table 4 Experimental Central Composite Design having coded values of independent variables along with their respective actual and predicted responses

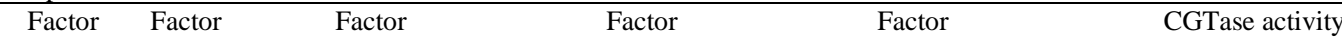

\begin{tabular}{|c|c|c|c|c|c|c|c|}
\hline & A & B & $\mathrm{C}$ & D & E & & \\
\hline Run & pH & Temp & $\begin{array}{l}\text { Incubation time } \\
\text { (h) }\end{array}$ & $\begin{array}{c}\text { Potato starch conc. } \\
\qquad(\%)\end{array}$ & $\begin{array}{l}\text { Agitation Speed } \\
\text { (rpm) }\end{array}$ & Actual & Predicted \\
\hline
\end{tabular}

\begin{tabular}{|c|c|c|c|c|c|c|c|}
\hline & & $\left({ }^{\circ} \mathrm{C}\right)$ & & & & & \\
\hline 1 & -1 & +1 & +1 & +1 & +1 & $30.12 \pm 0.0832$ & 32.55 \\
\hline 2 & 0 & 0 & 0 & 0 & 0 & $39.09 \pm 0.0456$ & 38.43 \\
\hline 3 & 0 & 0 & 0 & 0 & 0 & $40.21 \pm 0.0520$ & 41.44 \\
\hline 4 & 0 & 0 & 0 & 0 & -1 & $38.28 \pm 0.0789$ & 36.88 \\
\hline 5 & 0 & 0 & 0 & 0 & 0 & $39.01 \pm 0.0571$ & 38.50 \\
\hline 6 & -1 & +1 & -1 & -1 & -1 & $24.32 \pm 0.0351$ & 25.01 \\
\hline 7 & +1 & -1 & +1 & -1 & +1 & $21.41 \pm 0.0411$ & 22.69 \\
\hline 8 & 0 & 0 & 0 & -1 & 0 & $36.15 \pm 0.0642$ & 35.76 \\
\hline 9 & 0 & 0 & 0 & +1 & 0 & $38.25 \pm 0.0587$ & 39.23 \\
\hline 10 & +1 & -1 & +1 & -1 & -1 & $23.00 \pm 0.0935$ & 22.56 \\
\hline 11 & +1 & +1 & +1 & +1 & -1 & $26.27 \pm 0.0847$ & 27.12 \\
\hline 12 & -1 & -1 & -1 & -1 & -1 & $25.19 \pm 0.0863$ & 24.14 \\
\hline 13 & -1 & +1 & +1 & -1 & -1 & $25.34 \pm 0.0572$ & 24.95 \\
\hline 14 & -1 & +1 & -1 & +1 & -1 & $24.03 \pm 0.0637$ & 24.19 \\
\hline 15 & +1 & +1 & -1 & +1 & +1 & $26.53 \pm 0.0825$ & 25.08 \\
\hline 16 & -1 & +1 & +1 & -1 & +1 & $24.08 \pm 0.0790$ & 23.72 \\
\hline 17 & +1 & -1 & +1 & +1 & -1 & $25.12 \pm 0.1312$ & 24.65 \\
\hline 18 & 0 & 0 & +1 & 0 & 0 & $36.43 \pm 0.0551$ & 35.01 \\
\hline 19 & 0 & 0 & 0 & 0 & 0 & $39.16 \pm 0.0645$ & 38.27 \\
\hline 20 & -1 & +1 & -1 & +1 & +1 & $29.02 \pm 0.0873$ & 29.55 \\
\hline 21 & +1 & -1 & -1 & -1 & +1 & $26.35 \pm 0.0468$ & 26.00 \\
\hline 22 & 0 & 0 & 0 & 0 & 0 & $40.23 \pm 0.0388$ & 39.89 \\
\hline 23 & +1 & -1 & -1 & -1 & -1 & $27.45 \pm 0.0740$ & 26.11 \\
\hline 24 & 0 & 0 & 0 & 0 & 0 & $39.36 \pm 0.0490$ & 38.15 \\
\hline 25 & -1 & -1 & -1 & +1 & -1 & $25.48 \pm 0.0217$ & 24.23 \\
\hline 26 & 0 & 0 & 0 & 0 & 0 & $40.01 \pm 0.0513$ & 39.46 \\
\hline 27 & +1 & +1 & -1 & -1 & +1 & $22.35 \pm 0.0683$ & 23.07 \\
\hline 28 & -1 & -1 & +1 & -1 & -1 & $24.42 \pm 0.0879$ & 25.32 \\
\hline 29 & -1 & +1 & -1 & -1 & +1 & $27.14 \pm 0.0320$ & 28.12 \\
\hline 30 & 0 & 0 & -1 & 0 & 0 & $40.12 \pm 0.0469$ & 39.88 \\
\hline 31 & +1 & -1 & -1 & +1 & -1 & $28.50 \pm 0.0553$ & 27.78 \\
\hline 32 & 0 & 0 & 0 & 0 & 0 & $41.00 \pm 0.1231$ & 39.59 \\
\hline 33 & -1 & -1 & +1 & +1 & -1 & $23.23 \pm 0.0434$ & 24.52 \\
\hline 34 & +1 & +1 & -1 & -1 & -1 & $20.01 \pm 0.0659$ & 19.00 \\
\hline 35 & +1 & +1 & +1 & -1 & -1 & $21.17 \pm 0.0347$ & 20.25 \\
\hline 36 & +1 & -1 & -1 & +1 & +1 & $28.25 \pm 0.0897$ & 29.12 \\
\hline 37 & +1 & +1 & +1 & -1 & +1 & $19.22 \pm 0.0923$ & 18.77 \\
\hline 38 & +1 & +1 & +1 & +1 & +1 & $24.36 \pm 0.0230$ & 25.45 \\
\hline 39 & +1 & 0 & 0 & 0 & 0 & $34.43 \pm 0.0546$ & 35.12 \\
\hline 40 & 0 & +1 & 0 & 0 & 0 & $38.58 \pm 0.0681$ & 39.95 \\
\hline 41 & -1 & +1 & +1 & +1 & -1 & $28.32 \pm 0.1280$ & 27.00 \\
\hline 42 & +1 & -1 & +1 & +1 & +1 & $27.23 \pm 0.0404$ & 26.83 \\
\hline 43 & 0 & -1 & 0 & 0 & 0 & $39.41 \pm 0.0361$ & 38.65 \\
\hline 44 & +1 & +1 & -1 & +1 & -1 & $25.52 \pm 0.0343$ & 25.12 \\
\hline 45 & -1 & -1 & +1 & -1 & +1 & $28.34 \pm 0.0715$ & 29.55 \\
\hline 46 & 0 & 0 & 0 & 0 & +1 & $40.11 \pm 0.0591$ & 39.43 \\
\hline 47 & -1 & -1 & +1 & +1 & +1 & $29.02 \pm 0.0624$ & 28.52 \\
\hline 48 & -1 & 0 & 0 & 0 & 0 & $36.53 \pm 0.0838$ & 38.56 \\
\hline 49 & -1 & -1 & -1 & -1 & +1 & $30.24 \pm 0.0449$ & 28.65 \\
\hline 50 & -1 & -1 & -1 & +1 & +1 & $31.53 \pm 0.0215$ & 28.18 \\
\hline
\end{tabular}

The statistical and mathematical model fitness was assessed using ANOVA test (Table 5). The inferior probability value $(<0.001)$ and a greater F-value (104.76), along with the decent coefficient of determination value $\left(\mathrm{R}^{2}-0.9863\right)$ represents that model was highly efficient in predicting response values. As presented in Table 5, all the terms of independent parameters (A to E) including linear, interaction, and square were significant as they possessed the $p$-values $<0.05$. The
Lack of Fit F-value was not significant which implies that model was of good fit. The observed adjusted and predicted $\mathrm{R}^{2}$ values were 0.9769 and 0.9540 respectively suggesting sensible agreement between the experimental and predicted values. The ratio of signal to noise was measured as 32.1999 , which denotes that model can potentially circumnavigate the design space. 
Table 5 Analysis of variance (ANOVA) for quadratic model

\begin{tabular}{ccccccc}
\hline Source & Sum of Squares & Df & Mean Square & F-value & p-value & \\
\hline Model & 2254.08 & 20 & 112.70 & 104.76 & $<0.0001$ & significant \\
A-pH & 47.06 & 1 & 47.06 & 43.74 & $<0.0001$ & significant \\
B-Temp & 21.44 & 1 & 21.44 & 19.93 & 0.0001 & significant \\
C-Incubation time & 16.94 & 1 & 16.94 & 15.75 & 0.0004 & significant \\
D- Potato starch concentration & 56.94 & 1 & 56.94 & 52.93 & $<0.0001$ & significant \\
E-Agitation & 26.47 & 1 & 26.47 & 24.61 & $<0.0001$ & significant \\
AB & 10.13 & 1 & 10.13 & 9.41 & 0.0046 & significant \\
AC & 4.50 & 1 & 4.50 & 4.18 & 0.0500 & significant \\
AD & 10.13 & 1 & 10.13 & 9.41 & 0.0046 & significant \\
AE & 32.00 & 1 & 32.00 & 29.75 & $<0.0001$ & significant \\
BC & 12.50 & 1 & 12.50 & 11.62 & 0.0019 & significant \\
BD & 10.13 & 1 & 10.13 & 9.41 & 0.0046 & significant \\
BE & 4.50 & 1 & 4.50 & 4.18 & 0.0500 & significant \\
CD & 4.50 & 1 & 4.50 & 4.18 & 0.0500 & significant \\
CE & 6.13 & 1 & 6.13 & 5.69 & 0.0238 & significant \\
DE & 4.50 & 1 & 4.50 & 4.18 & 0.0500 & significant \\
$\mathbf{A}^{\mathbf{2}}$ & 72.42 & 1 & 72.42 & 67.32 & $<0.0001$ & significant \\
$\mathbf{B}^{2}$ & 9.03 & 1 & 9.03 & 8.40 & 0.0071 & significant \\
$\mathbf{C}^{2}$ & 14.38 & 1 & 14.38 & 13.37 & 0.0010 & significant \\
$\mathbf{D}^{2}$ & 28.78 & 1 & 28.78 & 26.75 & $<0.0001$ & significant \\
$\mathbf{E}^{2}$ & 4.93 & 1 & 4.93 & 4.58 & 0.0409 & significant \\
Lack of Fit & 27.32 & 22 & 1.24 & 2.24 & 0.1376 & Insignificant \\
Pure Error & 3.87 & 7 & 0.5536 & & & \\
Cor Total & 2285.28 & 49 & & & &
\end{tabular}

The interaction study of factors- $\mathrm{pH}$ and temperature showed that, at lower $\mathrm{pH}$ and temperature, enzyme activity was restricted which increased linearly and attained the peak values in the temperature range of $30^{\circ} \mathrm{C}$ to $35^{\circ} \mathrm{C}$ and $\mathrm{pH}$ range of 7.5 to 8.5. The enzyme activity decreased at increased temperature and $\mathrm{pH}$ (Figure 3A) The interaction between $\mathrm{pH}$ and incubation time interval explained that the CGTase production was maximum between 45 to $50 \mathrm{~h}$ of inoculation at $\mathrm{pH}$ range from 7.5 to 8.5 . The long term incubation even at lower or higher $\mathrm{pH}$ did not increase the enzyme activity (Figure 3B). As shown in Figure 3C, the potato starch concentration was a significant factor in the interaction of $\mathrm{pH}$ and potato starch concentration. The lower concentration of potato starch prohibited the enzyme activity irrespective of $\mathrm{pH}$. The enzyme activity was highest when the substrate concentration was taken in the range of 1.5 to $2.5 \%$ and the $\mathrm{pH}$ range of 7.5 to 8.5 . In the interaction studies between $\mathrm{pH}$ and agitation speed, it was observed that, when the isolate was cultured at lower $\mathrm{pH}$ with high agitation speed, the enzyme activity was in the increasing mode. However, the maximum level of enzyme activity was obtained when $\mathrm{pH}$ was adjusted in the range of 7.5-8.5 with the agitation speed range of 200 to $250 \mathrm{rpm}$ (Figure 3D). Figure 3E, shows that the incubation time interval is a critical operating parameter. The incubation of culture isolate in the temperature range of $30^{\circ} \mathrm{C}$ to $35^{\circ} \mathrm{C}$ for 40 to $45 \mathrm{~h}$ provides the maximum CGTase activity. The temperature and potato starch concentration interaction disclosed that the CGTase activity was more substrate concentration dependent. At lower substrate concentration the enzyme activity was minimum irrespective of temperature. However, the enzyme activity was maximum in the substrate concentration range of 1.5 to $2.5 \%$ and the temperature range of $30^{\circ} \mathrm{C}$ to $35^{\circ} \mathrm{C}$ (Figure $3 \mathrm{~F}$ ). As observed in Figure $3 \mathrm{G}$, the high agitation speed increased the enzyme activity in the temperature range of $30^{\circ} \mathrm{C}$ to $40^{\circ} \mathrm{C}$. The lower and higher incubation temperature than the provided, couldn't actively increase the enzyme activity at lower agitation speed. The interaction between incubation time and potato substrate concentration explained that there was minimal enzyme production at substrate concentration less than 1 irrespective of the incubation time interval. The increasing substrate concentration increased the CGTase activity which reached to the maximum in the time range of $40-50 \mathrm{~h}$ and 1.5 to $2.5 \%$ potato starch concentration range (Figure $3 \mathrm{H}$ ). Figure 3I, shows that the agitation speed in the range from 200 to $250 \mathrm{rpm}$ increased CGTase activity during the incubation time of 40 to $50 \mathrm{~h}$ when other factors were set to their standard levels. The interaction analysis of potato starch concentration and agitation speed revealed that the incorporation of 1.5 to $2.5 \%$ potato starch to the culture medium followed by adjusting the agitation speed to 200 to $250 \mathrm{rpm}$ could effectively increase the CGTase production (Figure $3 \mathrm{~J}$ )

The statistical model fitted all the selected operating factors to their optimum leve to provide the highest CGTase activity. The final model represented the optimal values of $\mathrm{pH}$, temperature, incubation time, potato starch concentration, and agitation speed to be as $8.8,38^{\circ} \mathrm{C}, 50 \mathrm{~h}, 2.2 \%$, and $200 \mathrm{rpm}$ respectively. To validate the method, CGTase production was experimented taking optimum values of the provided factors and the enzyme activity was measured as $38.313 \mathrm{U}$ which was similar to the activity calculated by software (39.901) and it was almost 2 folds higher than the conventional medium supplemented with potato starch. The variations in $\mathrm{pH}$ affected the enzyme production possibly by transporting chemicals through cell membrane (Sharma et al., 2017). The isolate SS2 produced maximum enzyme at $\mathrm{pH} 8.8$ which means the bacterium is moderately alkaliphilic. At the higher potato starch concentration, enzyme production was not observed as potato starch is viscous in nature and its higher concentration might lead to poor oxygen uptake that may reduce the enzyme production (BeMiller and Whistler, 2009). The enzyme production might also be repressed at higher substrate concentration due to the accumulation of short oligosaccharides and glucose units degraded from potato starch (Elbaz et al., 2015). The bacterium was able to produce enzyme in moderate substrate concentration. The operating parameters of incubation temperature, incubation time, and agitation speed were identified as growth attendant parameters, it was determined that the isolate produced optimal enzyme activity at the log phase which was characterized with the balanced values of these factors. The similar optimization report using CCD was studied before in Bacillus G1 where the optimization of various independent factors increased CGTase activity till $54.9 \mathrm{U} / \mathrm{mL}$ (Ibrahim et al., 2005). However, the manua optimization of multiple factors in Bacillus cereus RJ30 isolated produced maximum CGTase activity of 54U/mL (Jamuna et al., 1993), and in bacteria isolate Bacillus $s p$. TPR71H CGTase activity was measured as $30.34 \mathrm{U} / \mathrm{mL}$ (Ravinder et al., 2014).

The comparative results of CGTase production suggested that the selected factors profoundly influence the enzyme production and their interactions triggered the enzyme activity to reach the optimal level. The optimization study using the statistical approach of CCD generated encouraging and accurate results to enhance the enzyme production in bacterial isolate SS2. 


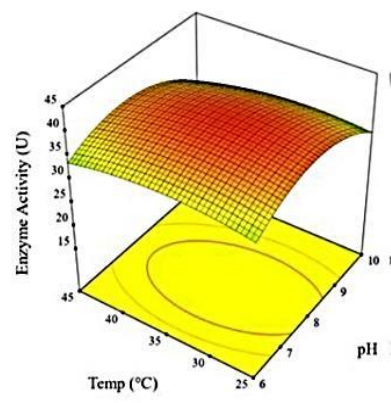

A

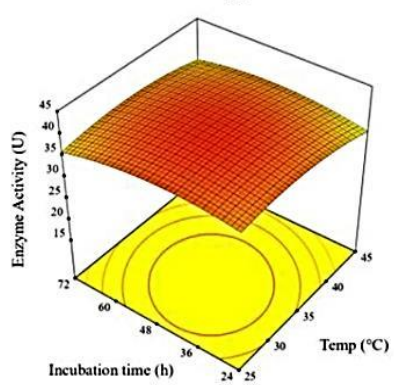

E

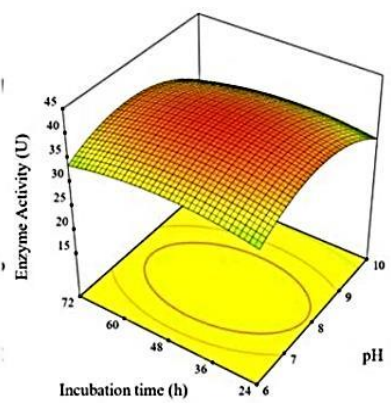

B

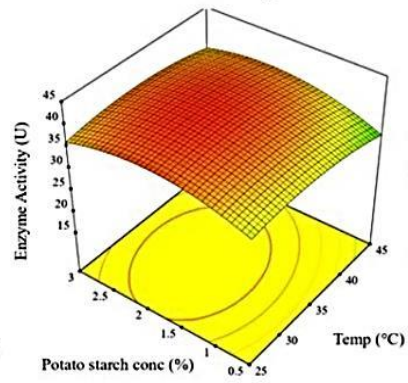

F

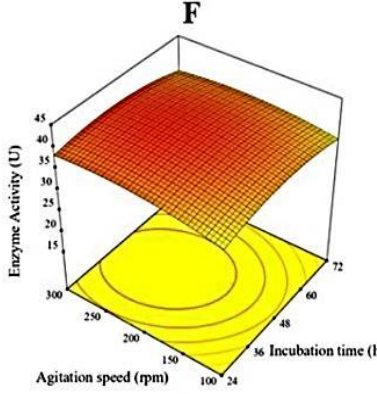

I

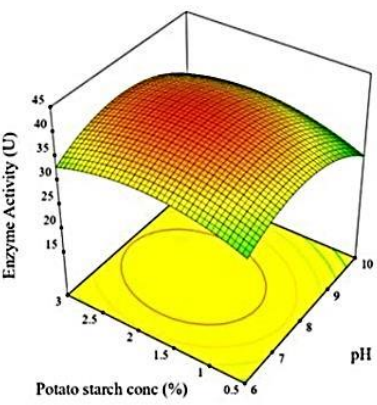

C

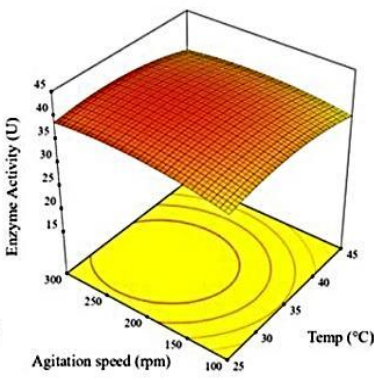

G

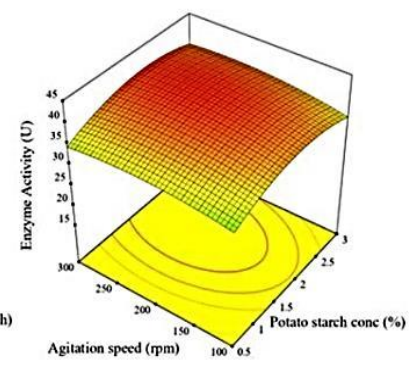

J

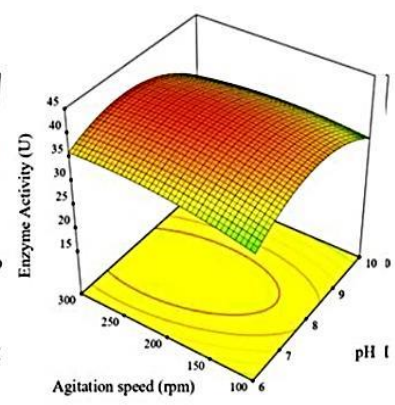

D

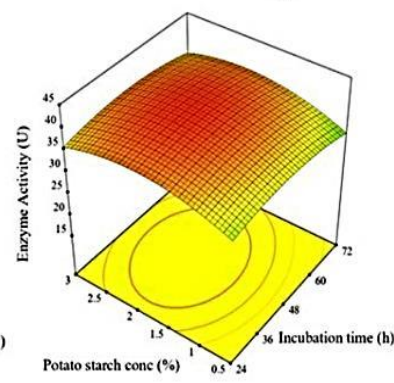

H

Figure 3 Three- dimensional Graphs showing interactions between: (A). pH and temp (B). pH and incubation time (C). pH and potato starch conc. (D). pH and agitation speed (E). Temp and incubation time (F). Temp and potato starch conc. (G). Temp and agitation speed (H). Incubation time and potato starch conc. (I). Incubation time and agitation speed (J). Potato starch conc. and agitation speed

\section{CONCLUSION}

The isolate SS2 is a potent CGTase producer which can effectively produce an enhanced amount of enzyme after optimization of the operating parameters. The bacterium can produce the enzyme in a wide thermal and $\mathrm{pH}$ range using various substrates. The main feature of isolate is the production of enzyme in alkaliphilic conditions which make it suitable for both research and industrial applications.

Acknowledgement: We would like to acknowledge Jaipur National University, Jaipur and Shri A.N. Patel P.G. Institute, Anand, Gujarat, India for providing the infrastructural support for these studies.

\section{REFERENCES}

Alves-Prado, H. F., Carneiro, A. A. J., Pavezzi, F. C., Gomes, E., Boscolo, M., Franco, C. M. L., \& da Silva, R. (2007). Production of Cyclodextrins by CGTase from Bacillus clausii Using Different Starches as Substrates. Applied Biochemistry and Biotechnology, 146(1-3), 3-13. https://doi.org/10.1007/s12010-007-8093-Z Atanasova, N., Kitayska, T., Bojadjieva, I., Yankov, D., \& Tonkova, A. (2011). A novel cyclodextrin glucanotransferase from alkaliphilic Bacillus pseudalcaliphilus 20RF: Purification and properties. Process Biochemistry, 46(1), 116-122. https://doi.org/10.1016/j.procbio.2010.07.027

Bautista, V., Esclapez, J., Pérez-Pomares, F., Martínez-Espinosa, R. M., Camacho, M., \& Bonete, M. J. (2012). Cyclodextrin glycosyltransferase: a key enzyme in the assimilation of starch by the halophilic archaeon Haloferax mediterranei. Extremophiles, 16(1), 147-159.

https://doi.org/10.1007/s00792-011-0414-z

BeMiller, J. N., \& Whistler, R. L. (Eds.). (2009). Starch: chemistry and technology. Academic Press. https://doi.org/10.1016/S1082-0132(08)X0009-3

Biwer, A., Antranikian, G., \& Heinzle, E. (2002). Enzymatic production of cyclodextrins. Applied Microbiology and Biotechnology, 59(6), 609-617. https://doi.org/10.1007/s00253-002-1057-X

Chun, J., Lee, J.-H., Jung, Y., Kim, M., Kim, S., Kim, B. K., \& Lim, Y.-W. (2007) EzTaxon: a web-based tool for the identification of prokaryotes based on $16 \mathrm{~S}$ ribosomal RNA gene sequences. International Journal of Systematic and Evolutionary Microbiology, 57(10), 2259-2261.

https://doi.org/10.1099/ijs.0.64915-0

Costa, H., Gastón, J. R., Lara, J., Martinez, C. O., Moriwaki, C., Matioli, G., \& Ferrarotti, S. A. (2015). Cyclodextrin glycosyltransferase production by free cells of Bacillus circulans DF 9R in batch fermentation and by immobilized cells in a semi-continuous process. Bioprocess and Biosystems Engineering, 38(6), 10551063. https://doi.org/10.1007/s00449-014-1347-6

De Oliveira, C. C., de Souza, A. K. S., \& de Castro, R. J. S. (2019). Bioconversion of Chicken Feather Meal by Aspergillus niger: Simultaneous Enzymes Production Using a Cost-Effective Feedstock Under Solid State Fermentation. Indian Journal of Microbiology, 59(2), 209-216. https://doi.org/10.1007/s12088-019-00792-3

Di Cagno, M.P. (2016). The Potential of Cyclodextrins as Novel Active Pharmaceutical Ingredients: A Short Overview. Molecules, 22(1), 1 https://doi.org/10.3390/molecules22010001

Elbaz, A. F., Sobhi, A., \& ElMekawy, A. (2015). Purification and characterization of cyclodextrin $\beta$-glucanotransferase from novel alkalophilic bacilli. Bioprocess and Biosystems Engineering, 38(4), 767-776. https://doi.org/10.1007/s00449-0141318-y

Felsenstein, J. (1985). Confidence limits on phylogenies: an approach using the bootstrap. Evolution, 39(4), 783-791. $\quad$ https://doi.org/10.1111/j.1558 5646.1985.tb00420.x

Goel, A. and Nene, S. (1995). A Novel Cyclomaltodextrin glucanotransferase from Bacillus firmus that Degrades Raw Starch. Biotechnology Letters, 17(4), 411-416. https://doi.org/10.1007/BF00130799

Horikoshi, K. (2003). Alkaliphiles: Alkaline Enzymes and their Applications. Encyclopedia of Environmental Microbiology. John Wiley \& Sons, Inc., New York. https://doi.org/10.1002/0471263397.env183

Ibrahim, A.S., Al-Salamah, A.A., El-Tayeb, M.A., El-Badawi, Y.B., Antranikian, G. (2012). A novel cyclodextrin glycosyltransferase from Alkaliphilic Amphibacillus sp. NPST-10: purification and properties. International Journal of Molecular Sciences, 13, 10505-10522. https://doi.org/10.3390/ijms130810505

Ibrahim, H.M, Yusoff, W.M.W., Hamid, A.A., Illias, R.M., Hassan, O., Omar, O (2005). Optimization of medium for the production of $\beta$-cyclodextrin 
glucanotransferase using Central Composite Design (CCD). Process Biochemistry, 40, 735-758. https://doi.org/10.1016/j.procbio.2004.01.042

Jamuna, R., Saswathi, N., Sheela, R., Ramakrishna, S.V. 1993. Synthesis of cyclodextrin glucosyl transferase by Bacillus cereus for the production of cyclodextrins. Applied Biochemistry and Biotechnology, 43, 163-176. https://doi.org/10.1007/BF02916450

Jansook, P., Ogawa, N., Loftsson, T. (2018). Cyclodextrins: structure, physicochemical properties and pharmaceutical applications. International $\begin{array}{llll}\text { Journal of } & \text { Pharmaceutics, } & \text { 535(1-2), }\end{array}$ https://doi.org/10.1016/j.ijpharm.2017.11.018

Kfoury, M., Lounès-Hadj, SA., Bourdon, N., Laruelle, F., Fontaine, J., Auezova L., Greige-Gerges, H., and Fourmentin, S. (2016). Solubility, photostability and antifungal activity of phenylpropanoids encapsulated in cyclodextrins. Food Chemistry, 196, 518-525. https://doi.org/10.1016/j.foodchem.2015.09.078

Kimura, M. A. (1980). A simple method for estimating evolutionary rates of base substitutions through comparative studies of nucleotide

sequences. Journal of Molecular Evolution, 16, 111-20 https://doi.org/10.1007/BF01731581

Kreig, R. N., \& Holt, G. J. (1984). In Bergey’s Manualof Systematic Bacteriology, William and Wilkins Co.

Kumar, P., Patel, S.K., Lee, J.K. and Kalia, V.C. (2013). Extending the limits of Bacillus for novel biotechnological applications. Biotechnology Advances, 31(8), 1543-1561. https://doi.org/10.1016/j.biotechadv.2013.08.007

Lee, M.H., Yang, S.J., Kim, J.W., Lee, H.S., Kim, J.W., Park, K.H. (2007) Characterization of a thermostable cyclodextrin glucanotransferase from Pyrococcus furiosus DSM3638. Extremophiles, 11, 537-541. https://doi.org/10.1007/s00792-007-0061-6

Leemhuis, H., Kelly, R. M., \& Dijkhuizen, L. (2009). Engineering of cyclodextrin glucanotransferases and the impact for biotechnological applications. Applied Microbiology and Biotechnology, 85(4), 823-835. https://doi.org/10.1007/s00253009-2221-3

Montgomery, D.C., Runger, G.C. and Hubele, N.F. (2009). Engineering statistics. John Wiley \& Sons

Park, C.S., Park, K.H., Kim, S.H. (1989). A rapid screening method for alkaline $\beta$ cyclodextrin glucanotransferase using phenolphthalein-methyl orange containing solid medium. Agricultural and Biological Chemistry, 53, 1167-1169. https://doi.org/10.1080/00021369.1989.10869443

Patel, S.K.S., Ray, S., Prakash, J. et al. (2019). Co-digestion of Biowastes to Enhance Biological Hydrogen Process by Defined Mixed Bacterial Cultures. Indian Journal of Microbiology, 59, 154-160 https://doi.org/10.1007/s12088-018-00777-8

Porwal, S., Kumar, T., Lal, S., Rani, A., Kumar, S., Cheema, S., Purohit, H.J., Sharma, R., Patel, S.K.S. and Kalia, V.C. (2008). Hydrogen and polyhydroxybutyrate producing abilities of microbes from diverse habitats by dark fermentative process. Bioresource Technology,99(13), 5444-5451. https://doi.org/10.1016/j.biortech.2007.11.011

Qi, Q., and Zimmermann, W. (2004). Cyclodextrin glucanotransferase: from gene to applications. Applied Microbiology and Biotechnology, 66(5), 475-485. https://doi.org/10.1007/s00253-004-1781-5

Rajput, K.N., Patel, K.C., Trivedi, U.B. (2016). $\beta$-cyclodextrin production by cyclodextrin glucanotransferase from an alkaliphile Microbacterium terrae KNR 9 using different starch substrates. Biotechnology Research International, 7, 1-7. https://doi.org/10.1155/2016/2034359

Rashid, N., Cornista, J., Ezaki, S., Fukui, T., Atomi, H., Imanaka, T. (2002) Characterization of an archaeal cyclodextrin glucanotransferase with a novel Cterminal domain. Journal of Bacteriology, 184, 777-784. http://doi.org/10.1128/JB.184.3.777-784.2002

Ravinder, K., Prabhakar, T., Prashanthkumar K, Venuka N. (2014). Optimization of Process Parameters of Cyclodextrin Glycosyltransferase isolated from Nove Mutated Bacillus Sp. TPR71HNA6 by Taguchi Orthogonal Array Method. Research in Biotechnology, 5(3), 10-20.

Reddy, S.V., More, S.S., Annappa, G.S. (2017). Purification and properties of $\beta$ cyclomaltodextrin glucanotransferase from Bacillus flexus

SV1. Journal of Basic Microbiology, 57, 974-981. https://doi.org/10.1002/jobm.201700270

Saitou, N. and Nei, M. (1987). The neighbour-joining method: a new method for constructing phylogenetic trees. Molecular Biology and Evolution, 4, 406-425. https://doi.org/10.1093/oxfordjournals.molbev.a040454

Sharma, N. and Baldi, A. (2016). Exploring versatile applications of cyclodextrins: an overview. Drug Delivery, 23, 729-47. https://doi.org/10.3109/10717544.2014.938839

Sharma, K. M., Kumar, R., Panwar, S., Kumar, A. (2017). Microbial alkaline proteases: Optimization of production parameters and their properties. Journal of Genetic Engineering and Biotechnology, 15(1), 115-126. https://doi.org/10.1016/j.jgeb.2017.02.001

Staley, J. T. (1989). Bergey's manual of systematic bacteriology. Williams \& Wilkins.
Tamura, K., Dudley, J., Nei, M., Kumar, S. (2007). MEGAX: Molecular Evolutionary Genetics Analysis (MEGA) software version X. Molecular Biology and Evolution, 24, 1596-1599. https://doi.org/10.1093/molbev/msm092

Sreedharan, S.M., Singh, S.P. \& Singh, R. (2019). Flower Shaped Gold Nanoparticles: Biogenic Synthesis Strategies and Characterization. Indian J Microbiol, 59, 321-327. https://doi.org/10.1007/s12088-019-00804-2

Upadhyay, D., Sharma, S., Shrivastava, D., Kulshreshtha, N.M. (2018). Production and characterization of of $\beta$-cyclodextrin

glucanotransferase from Bacillus sp. ND1. Journal of Basic Microbiology, 59(2), 192-205. https://doi.org/10.1002/jobm.201800390

Vining, G.G. and Kowalski, S. (2010). Statistical methods for engineers. Cengage Learning.

Vinod, A. S., and More, S. M. (2016). Purification and Characterization of a Nove CGTase from Alkaliphilic Bacillus flexus Isolated from Lonar lake, India International Journal of Current Microbiology and Applied Science, 5(7), 164 170. https://doi.org/10.20546/ijcmas.2016.507.016

Wu, D., Chen, S., Wang,N., Chen, J., Wu, J. (2012). Gamma-cyclodextrin production using cyclodextrin glycosyltransferase from Bacillus clarkii 7364 Applied Biochemistry and Biotechnology, 167(7), 1954-1962. https://doi.org/10.1007/s12010-012-9741-5 